\title{
Electrochemical and in situ spectroelectrochemical studies of gold nanoparticles immobilized Nafion matrix modified electrode
}

\author{
T SELVARAJU, S SIVAGAMI, S THANGAVEL and R RAMARAJ* \\ School of Chemistry, Madurai Kamaraj University, Madurai 625 021, India
}

\begin{abstract}
Electrochemical and in situ spectroelectrochemical behaviours of phenosafranine $\left(\mathrm{PS}^{+}\right)$were studied at the gold nanoparticles $\left(\mathrm{Au}_{\mathrm{Nps}}\right)$ immobilized Nafion $(\mathrm{Nf})$ film coated glassy carbon $(\mathrm{GC})$ and indium tin oxide (ITO) electrodes. Cyclic voltammetric studies showed that the $\mathrm{PS}^{+}$molecules strongly interact with the $\mathrm{Au}_{\mathrm{Nps}}$ immobilized in the $\mathrm{Nf}$ matrix through the electrostatic interaction. The presence of $\mathrm{Au}_{\mathrm{Nps}}$ in the $\mathrm{Nf}$ film improved the electrochemical characteristics of the incorporated dye molecules. The emission spectra of $\mathrm{Nf}-\mathrm{Au}_{\mathrm{Nps}}-\mathrm{PS}^{+}$films showed that the incorporated $\mathrm{PS}^{+}$was quenched by $\mathrm{Au}_{\mathrm{Nps}}$ and it could be explained based on the electronic interaction between the $\mathrm{Au}_{\mathrm{Nps}}$ and $\mathrm{PS}^{+}$molecules. The in situ spectroelectrochemical study showed an improved electrochemical characteristic of the incorporated PS ${ }^{+}$molecules at the ITO/Nf- $\mathrm{Au}_{\mathrm{Nps}}$ electrode when compared to the ITO/Nf electrode.
\end{abstract}

Keywords. Gold nanoparticles; Nafion; modified electrode; phenosafranine; in situ spectroelectrochemistry.

\section{Introduction}

In recent years, interest in electrocatalysis and sensors has soared because of the technological advances that have been made, especially in materials science and device miniaturization (Eggins 2002). The preparation of thin films with high density of metal nanoparticles is often desired for catalysis and electronics (Niemeyer 2001). The integration of metal nanoparticles in thin films is particularly important for various applications, for example, in biological sensing and in the preparation of optoelectronic, advanced photonic and nanodevices (Rodriguez et al 2002; Xiao et al 2003; Haruta 2004; Xu et al 2004). Although gold is a poor catalyst in bulk form, nanometersized gold particles can exhibit excellent catalytic activity due to their relative high surface area-to-volume ratio, arrangement of atom, electronic structure and their interface dominated properties, which significantly differ from their bulk counterparts (Henglein 1989; Kreibig and Vollmer 1995; Shipway et al 2000; Hu et al 2001; Ipe et al 2002; Sudeep et al 2002; Thomas and Kamat 2003; Campbell 2004; Daniel and Astruc 2004; Clapp et al 2005). The modification of electrode surface with nanosized noble metals can enhance the sensing activities of the electrode by mediating the electron transfer properties (Linsebigler and Lu 1995; Selvaraju and Ramaraj 2005). However, only a few studies have reported the effect of metal nanoparticles modification on the electrode surface and its applications (Yao et al 1998; George et al 2000; Wildgoose et al 2006).

*Author for correspondence (ramarajr@yahoo.com)
We are interested in developing the gold nanoparticles immobilized Nafion film coated electrode for the study of electrochromic properties of molecules and to develop electrochemical sensors. The in situ spectral measurements of molecules under potential scanning have rarely been carried out especially in metal nanoparticles incorporated systems. It is, therefore, important to investigate the redox behaviour of molecules, especially electroactive and photoactive molecules at metal nanoparticles modified electrodes (Radovic 1999; Gonzalez-Garcia et al 2002; Aray et al 2003; Eckenrode et al 2005). Phenazine dye, such as phenosafranine, has been used in the studies of photoelectrochemical cells (Newmann-Spallart and Kalyana Sundaram 1982; Ramaraj and Natarajan 1989), photosensitization of large band-gap semiconductor such as $\mathrm{TiO}_{2}$ (Gopidas and Kamat 1989, 1990; Easwaramoorthy and Natarajan 2005), electrocatalysis of NADH (Tanaka et al 1993) and electrochromism when loaded in Nafion membrane (Abraham John and Ramaraj 1997; Ganesan et al 2001). In this paper, a novel approach of dispersing the $\mathrm{Au}_{\mathrm{Nps}}$ in a $\mathrm{Nf}$ matrix is reported. Thus it brings together the advantageous properties of microheterogeneous structure with permselective and preconcentration properties of Nf matrix (Olah et al 1986; Abraham John and Ramaraj 1996; Mauritz and Moore 2004) and catalytically active $\mathrm{Au}_{\mathrm{Nps}}$ with high surface area-to-volume (Shenhar and Rotello 2003; Subramanian et al 2004; Barazzouk et al 2005). While the solid $\mathrm{Au}_{\mathrm{Nps}}$ were embedded in the hydrophobic and interfacial regions, the cationic molecules were ion-exchanged into the Nf matrix. This type of approach will find applications in electrocatalysis, sensors, photoelectrochemical cells and electrochromic systems. In view of these considerations, we have chosen a cationic pheno- 
safranine dye and gold nanoparticles to prepare the modified electrode and to investigate the influence of $\mathrm{Au}_{\mathrm{Nps}}$ on the immobilized dye molecules in the Nf film.

\section{Experimental}

\subsection{Chemicals}

Chloroauric acid $\left(\mathrm{HAuCl}_{4}\right)$ and sodium citrate of analar grade were used as received. Phenosafranine (Aldrich) was used after purification (Gopidas and Kamat 1990). A $5 \%$ Nafion (Nf) solution (Aldrich, EW 1100, dissolved in a mixture of lower aliphatic alcohol and water) was diluted to $1 \%$ with ethanol. Double distilled water was used throughout the experiments. Nitrogen gas was used for deaerating the solution. One side deposited indium tin oxide plates (CG-411N-1507, Delta Technologies Ltd., USA) with a surface resistance of $4-8 \Omega \mathrm{sq}^{-1}$ was used to fabricate transparent electrodes. The $\sim 0.7 \mathrm{~mm}$ thickness strips $(1.5 \times 1 \mathrm{~cm})$ were incised and cleaned in acetone, ethanol and in double distilled water.

\subsection{Preparation of spherical colloidal Au nanoparticles by sodium citrate reduction method}

Spherical colloidal Au nanoparticles were prepared by citrate reduction of $\mathrm{HAuCl}_{4}$ in aqueous solution using reported procedure (Daweipan 2004). $1.8 \mathrm{ml}$ of $1 \%$ sodium citrate solution was added to $50 \mathrm{ml}$ of $0.01 \%$ $\mathrm{HAuCl}_{4}$ boiling solution. The solution was refluxed for 15 min until a wine red colour was observed. The surface plasmon band observed at $519 \mathrm{~nm}$ confirmed that the colloidal Au nanoparticles have been successfully synthesized by sodium citrate reduction method. The citrate ions act as capping agent and prevent colloidal Au nanoparticles from further agglomeration. The literature reports show the size of Au nanoparticles to be in the range of 15$20 \mathrm{~nm}$ (Daniel and Astruc 2004; Daweipan 2004).

\subsection{Immobilization of colloidal Au nanoparticles in Nafion matrix}

The glass vials were washed and dried in the oven. The required volume $(\mathrm{v} / \mathrm{v})$ of $0.5 \mathrm{ml}$ of $1 \% \mathrm{Nafion}^{\circledR}$ solution was taken in the sample tube and a known amount of $(0.25 \mathrm{ml} / 0.5 \mathrm{ml})$ colloidal Au nanoparticles was added slowly to the Nafion ${ }^{\circledR}$ solution and the mixture was stirred for $10 \mathrm{~min}$ using magnetic stirrer. The volume ratio with respect to Nafion and colloidal $\mathrm{Au}$ nanoparticles were $1: 1$ and $2: 1(\mathrm{v} / \mathrm{v})$. The immobilized colloidal Au nanoparticles in Nafion matrix containing viols were corked tightly and stored in refrigerator. By cast coating method, the $\mathrm{Au}_{\mathrm{Nps}}$ dispersed Nafion was coated on the GC and ITO electrodes ( $\mathrm{GC} / \mathrm{Nf}-\mathrm{Au}_{\mathrm{Nps}}$ and ITO/Nf-A $\left.\mathrm{u}_{\mathrm{Nps}}\right)$ and from the amount of $\mathrm{Nf}$ taken the film thickness was calculated as $1.6 \mu \mathrm{m}$.

\subsection{Equipment and measurements}

All the electrochemical and in situ spectroelectrochemical experiments were performed in an EG\&G PAR model 283 potentiostat/galvanostat with Echem software and HP diode array spectrophotometer (Agilent technologies8453) with HPchem software loaded computers. The electrochemical and in situ spectroelectrochemical experiments were carried out with a single compartment threeelectrode system, which has platinum wire as the counter electrode, saturated calomel electrode (SCE) or $\mathrm{Ag}$ wire as the reference electrode and $\mathrm{GC}\left(0.07 \mathrm{~cm}^{2}\right)(\mathrm{CH}$ Instruments) or ITO $\left(1 \mathrm{~cm}^{2}\right)$ coated glass electrode as the working electrode. Prior to every experiment, the GC electrodes were polished with an aqueous suspension of $1 \mu \mathrm{m}$ alumina on a soft surface, rinsed copiously with doubly distilled water and sonicated in a water bath for $3 \mathrm{~min}$. The electrode was then rinsed with distilled water and ethanol. The cleaned electrode was transferred to the electrochemical cell and pretreated by cycling the potential between -0.2 and $1.2 \mathrm{~V}$ at a scan rate of $20 \mathrm{mVs}^{-1}$ in $0 \cdot 1 \mathrm{M}$ phosphate buffer $(\mathrm{pH} 7 \cdot 2)$ until a stable cyclic voltammogram was obtained. For the activation of electrode surface, the potential was stepped to $1.2 \mathrm{~V}$ for $2 \mathrm{~min}$. The activated electrode was immediately used for electrochemical experiments.

\section{Results and discussion}

\subsection{Spectral characterization of $A u_{N p s}$ in Nafion film}

The absorption spectra of the colloidal $A u_{\mathrm{Nps}}$ and $\mathrm{Au}_{\mathrm{Nps}}$ dispersed in $0.5 \%$ Nafion solution $\left(\mathrm{Nf}-\mathrm{Au}_{\mathrm{Nps}}\right)$ are shown in figure 1 . The surface plasmon absorption bands for the $\mathrm{Au}_{\mathrm{Nps}}$ and $\mathrm{Nf}-\mathrm{Au}_{\mathrm{Nps}}$ were observed at 519 and $521 \mathrm{~nm}$, respectively with an average diameter of $\mathrm{Au}_{\mathrm{Nps}}$ in the range

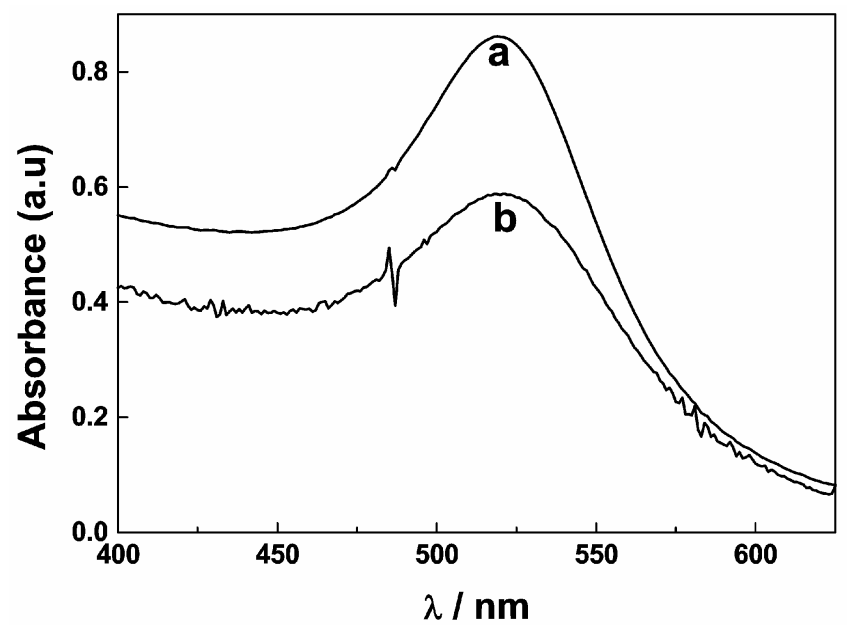

Figure 1. Absorption spectra of $\mathrm{Au}_{\mathrm{Nps}}$ (a) and $\mathrm{Nf}-\mathrm{Au}_{\mathrm{Nps}}$ (b) in aqueous and $0.5 \%$ Nafion solution. 
15-20 nm (Daniel and Astruc 2004; Daweipan 2004). The surface plasmon band of the $\mathrm{Nf}-\mathrm{Au}_{\mathrm{Nps}}$ exhibits a small red shift of $2 \mathrm{~nm}$ with bandwidth broadening. The change in the steady-state spectrum of the $\mathrm{Nf}-\mathrm{Au}_{\mathrm{Nps}}$ was due to the difference in the dielectric constant of the surrounding medium and embedding material ( $\mathrm{Su}$ et al 2003; Yan et al 2003). When known amount of $\mathrm{Nf}-\mathrm{Au}_{\mathrm{Nps}}$ was coated on a glass plate (the amount used to prepare modified electrodes), the $\mathrm{Nf}-\mathrm{Au}_{\mathrm{Nps}}$ film did not show observable absorption band due to very small amount of $\mathrm{Au}_{\mathrm{Nps}}$ dispersed in the Nf film.

\subsection{Characterization of $A u_{N p s}$ immobilized Nafion film coated GC electrode}

The voltammetric procedure was used to study the 'fingerprint' characteristics of gold nanoparticles. The voltammetric responses were recorded for plain $\mathrm{GC}$ and $\mathrm{Nf}-$ $\mathrm{Au}_{\mathrm{Nps}}$ modified $\mathrm{GC}$ electrodes in $0.1 \mathrm{M} \mathrm{H}_{2} \mathrm{SO}_{4}$. In the absence of $\mathrm{Nf}-\mathrm{Au}_{\mathrm{Nps}}$ on the $\mathrm{GC}$ electrode, no electrochemical peak was observed either in the anodic or cathodic scan. However, the $\mathrm{Nf}-\mathrm{Au}_{\mathrm{Nps}}$ modified $\mathrm{GC}$ electrode exhibited a sharp reduction peak at $0.8 \mathrm{~V}$ due to the reduction of surface oxides of gold nanoparticles (figure 2) (Trasatti and Petrii 1991; Dai et al 2006). This observation shows that the $\mathrm{Au}_{\mathrm{Nps}}$ in $\mathrm{Nf}$ film are indeed formed from the dispersed gold nanoparticles and that they are in good electrical contact with the macroelectrode surface (Trasatti and Petrii 1991; Hoogvliet et al 2000; Dai et al 2006). One of the well established advantages of using the metal nanoparticles (e.g. metal nanoparticles modified electrode) is the significantly large electroactive surface area when compared to the bulk metal electrode.

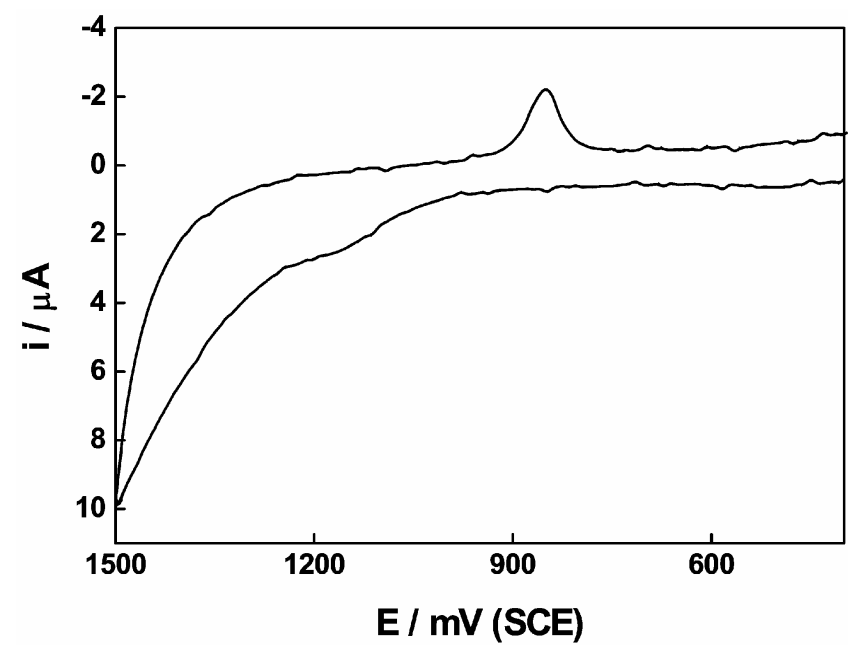

Figure 2. Cyclic voltammogram of $\mathrm{Au}_{\mathrm{Nps}}$ immobilized $\mathrm{Nf}$ film modified $\mathrm{GC}$ electrode $\left(\mathrm{GC} / \mathrm{Nf} / \mathrm{Au}_{\mathrm{Nps}}\right)$ in $0 \cdot 1 \mathrm{M} \mathrm{H}_{2} \mathrm{SO}_{4}$ (Scan rate $=50 \mathrm{mV} \mathrm{s}^{-1}$. [Au] $\left.=2.57 \times 10^{-13} \mathrm{~mol}\right)$.
3.3 Electrochemical behaviour of $\mathrm{PS}^{+}$dye in $\mathrm{GC} / \mathrm{Nf}$ and $G C / N f-A u_{N p s}$ electrodes

The electrochemical properties of $\mathrm{PS}^{+}$were studied by recording the cyclic voltammograms for $\mathrm{GC} / \mathrm{Nf} / \mathrm{PS}^{+}$and $\mathrm{GC} / \mathrm{Nf}-\mathrm{Au}_{\mathrm{Nps}} / \mathrm{PS}^{+}$electrodes in $0 \cdot 1 \mathrm{M} \mathrm{H}_{2} \mathrm{SO}_{4}$ at different scan rates as shown in figures 3 and 4, respectively. The $\mathrm{PS}^{+}$dye undergoes two-electron and two-proton reduction (1) (Tanaka et al 1993). The $\mathrm{PS}^{+}$dye showed an $E_{1 / 2}$ value of $-0.07 \mathrm{~V}$ and $-0.06 \mathrm{~V}$ (SCE) at the GC/Nf/PS ${ }^{+}$and $\mathrm{GC} / \mathrm{Nf}-\mathrm{Au}_{\mathrm{Nps}} / \mathrm{PS}^{+}$electrodes, respectively. This observa-

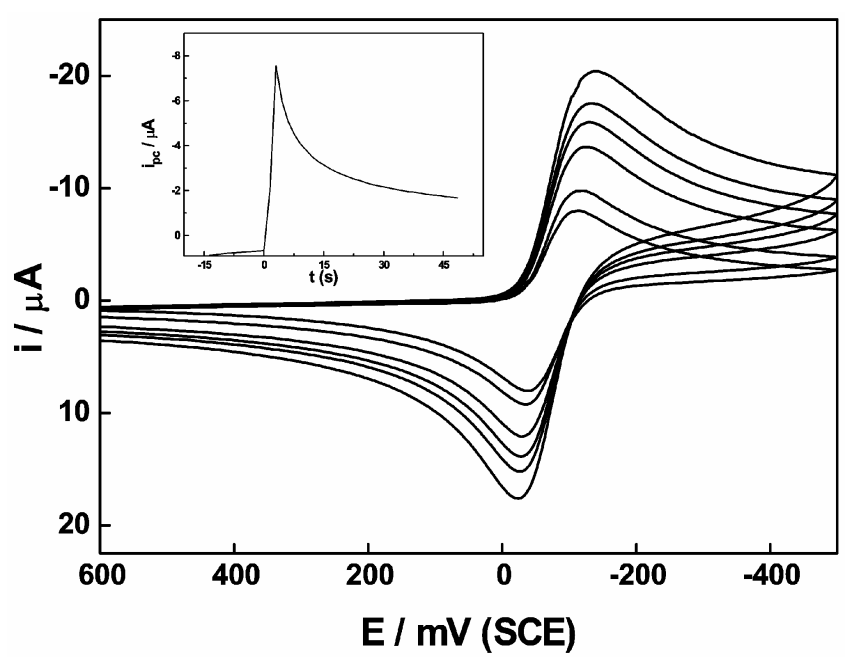

Figure 3. Cyclic voltammograms observed for $\mathrm{GC} / \mathrm{Nf} / \mathrm{PS}^{+}$ electrode in $0 \cdot 1 \mathrm{M} \mathrm{H}_{2} \mathrm{SO}_{4}$. Scan rate $=10,20,50,75,100$ and $150 \mathrm{mV} / \mathrm{s}$. Inset: Chronoamperometry response observed for the same electrode in $0.1 \mathrm{M} \mathrm{H}_{2} \mathrm{SO}_{4}$. (Electroactive $\mathrm{PS}^{+}(\Gamma)=$ $0.88 \times 10^{-8} \mathrm{~mol} / \mathrm{cm}^{2}$ ).

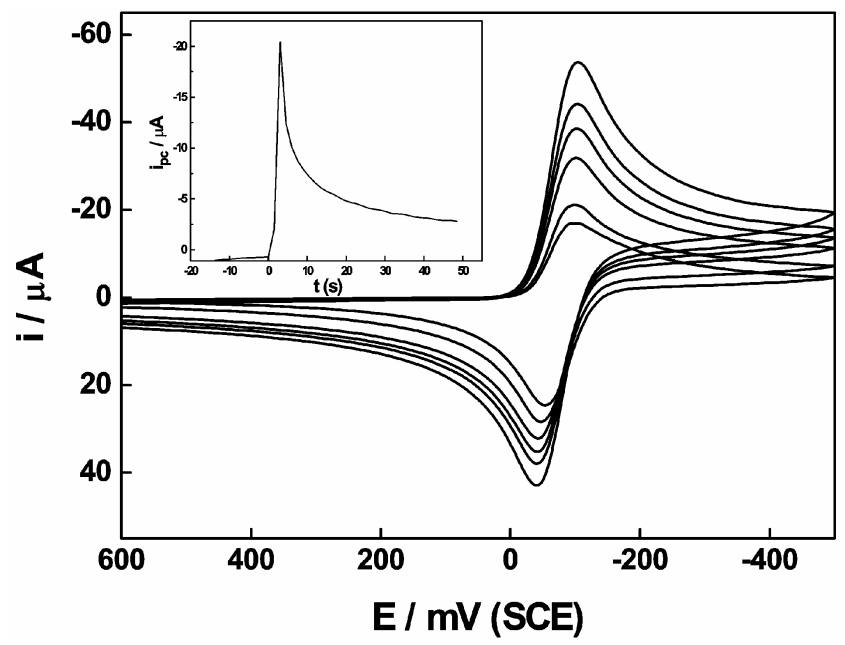

Figure 4. Cyclic voltammograms observed for GC/Nf$\mathrm{Au}_{\mathrm{Nps}} / \mathrm{PS}^{+}$electrode in $0 \cdot 1 \mathrm{M} \mathrm{H}_{2} \mathrm{SO}_{4}$. Scan rate $=10,20,50,75$, 100 and $150 \mathrm{mV} / \mathrm{s}$. Inset: Chronoamperometry response observed for the same electrode in $0.1 \mathrm{M} \mathrm{H}_{2} \mathrm{SO}_{4}$. (Electroactive $\left.\operatorname{PS}^{+}(\Gamma)=1.53 \times 10^{-8} \mathrm{~mol} / \mathrm{cm}^{2}\right)$. $[\mathrm{Au}]=2.57 \times 10^{-13} \mathrm{~mol}$. 
tion shows that the redox potential of $\mathrm{PS}^{+}$is not changed significantly at the $\mathrm{GC} / \mathrm{Nf}-\mathrm{Au}_{\mathrm{Nps}}$ electrode.

$$
\mathrm{PS}^{+}+2 e^{-}+2 \mathrm{H}^{+} \rightleftharpoons \mathrm{PSH}_{2}^{+}
$$

The reversibility was improved and enhanced peak currents were observed at the $\mathrm{GC} / \mathrm{Nf}-\mathrm{Au}_{\mathrm{Nps}} / \mathrm{PS}^{+}$electrode for $\mathrm{PS}^{+}$molecule (figure 4) when compared to $\mathrm{GC} / \mathrm{Nf} / \mathrm{PS}^{+}$ electrode without $\mathrm{Au}_{\mathrm{Nps}}$ (figure 3). The increase in the peak currents due to $\mathrm{PS}^{+}$redox process observed at the $\mathrm{GC} / \mathrm{Nf}-\mathrm{Au}_{\mathrm{Nps}} / \mathrm{PS}^{+}$electrode (figure 4 ) when compared to the $\mathrm{GC} / \mathrm{Nf} / \mathrm{PS}^{+}$electrode (figure 3 ) clearly shows that the redox reaction of $\mathrm{PS}^{+}$at $\mathrm{Au}$ nanoparticles is significantly improved with fast electron transfer kinetics. The nitrogen atoms of the $-\mathrm{NH}_{2}$ moieties of the cationic $\mathrm{PS}^{+}$bind strongly to $\mathrm{Au}_{\mathrm{Nps}}$ (Ding et al 2006) immobilized in $\mathrm{Nf}$ matrix and hence the electrostatic interaction plays an important role in increasing the reversibility and peak currents. Scheme 1 depicts the schematic representation of the interaction of dispersed $\mathrm{Au}_{\mathrm{Nps}}$ and their interaction with the incorporated $\mathrm{PS}^{+}$dye at the $\mathrm{Nf}-\mathrm{Au}_{\mathrm{Nps}}$ modified electrodes. The linear plot observed for the cathodic $\left(i_{\mathrm{pc}}\right)$

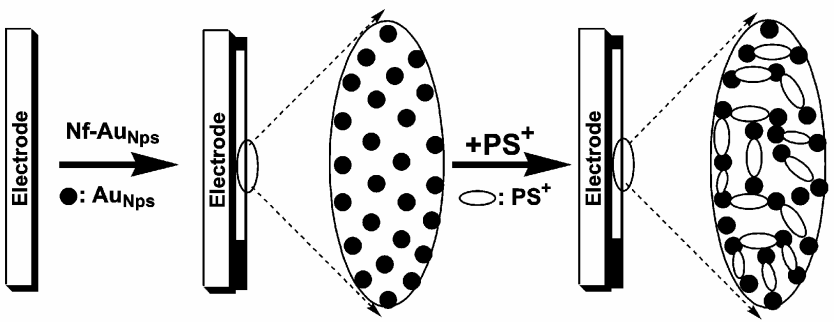

Scheme 1. Schematic representation of interaction of $\mathrm{PS}^{+}$ molecules with dispersed $\mathrm{Au}_{\mathrm{Nps}}$ in $\mathrm{Nf}$ film.

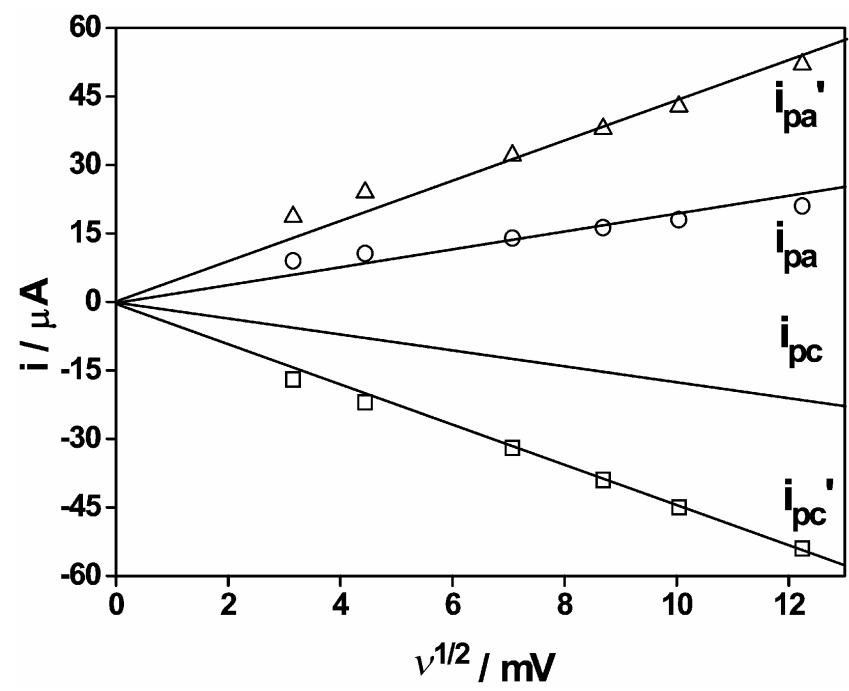

Figure 5. Plots of cathodic $\left(i_{\mathrm{pc}}\right.$ and $\left.i_{\mathrm{pc}}\right)$ and anodic $\left(i_{\mathrm{pa}}\right.$ and $\left.i_{\mathrm{pa}^{\prime}}\right)$ peak currents against square root of scan rate $\left(v^{1 / 2}\right)$ at the $\mathrm{GC} / \mathrm{Nf} / \mathrm{PS}^{+}$and $\mathrm{GC} / \mathrm{Nf}-\mathrm{Au}_{\mathrm{Nps}} / \mathrm{PS}^{+}$electrodes, respectively. and anodic $\left(i_{\mathrm{pa}}\right)$ peak currents against square root of scan rate $\left(v^{1 / 2}\right)$ for $\mathrm{GC} / \mathrm{Nf} / \mathrm{PS}^{+}$and $\mathrm{GC} / \mathrm{Nf}-\mathrm{Au}_{\mathrm{Nps}} / \mathrm{PS}^{+}$electrodes confirm the diffusion-controlled processes at both the electrodes (figure 5). The rate of charge or mass transport associated with redox reaction at the modified electrode is commonly studied by determining the apparent diffusion coefficient ( $D_{\text {app }}$ ) (Martin et al 1984). The chronoamperometry method (Martin and Dollard 1983) was used to estimate the value of $D_{\text {app. }}$. The typical reductive single step chronoamperometry responses recorded for $\mathrm{GC} / \mathrm{Nf} / \mathrm{PS}^{+}$and $\mathrm{GC} / \mathrm{Nf}-\mathrm{Au}_{\mathrm{Nps}} / \mathrm{PS}^{+}$electrodes are shown in figures 3 (inset) and 4(inset). From the chronoamperometry plots, the molar concentration of electroactive $\mathrm{PS}^{+}$dye $\left(C_{\mathrm{p}}\right)$ (Chiba et al 1987) and the apparent diffusion coefficient $\left(D_{\text {app }}\right)$ were calculated as $5.51 \times$ $10^{-5} \mathrm{~mol} / \mathrm{cm}^{3}$ and $0.94 \times 10^{-9} \mathrm{~cm}^{2} / \mathrm{s}$ at $\mathrm{GC} / \mathrm{Nf} / \mathrm{PS}^{+}$electrode and $8.34 \times 10^{-5} \mathrm{~mol} / \mathrm{cm}^{3}$ and $1.34 \times 10^{-9} \mathrm{~cm}^{2} / \mathrm{s}$ at $\mathrm{GC} / \mathrm{Nf}-\mathrm{Au}_{\mathrm{Nps}}$ electrode. The molar concentration of electroactive $\mathrm{PS}^{+}$dye $\left(C_{\mathrm{p}}\right)$ was increased at the $\mathrm{GC} / \mathrm{Nf}-\mathrm{Au}_{\mathrm{Nps}}$ electrode when compared to the $\mathrm{GC} / \mathrm{Nf}$ electrode at the same amount of $\mathrm{Nf}$ in the film. The $\mathrm{PS}^{+}$dye incorporated into the hydrophobic region of the Nf film are electroinactive (Guadalupe et al 1991). When $\mathrm{Au}_{\mathrm{Nps}}$ were embedded into the Nf film, in addition to the hydrophobic and interfacial regions, more amount of $\mathrm{PS}^{+}$dye would occupy the expanded $-\mathrm{SO}_{3}^{-}$ionic cluster region of the $\mathrm{Nf}$ film. The molecules occupying the ionic cluster and interfacial regions of the $\mathrm{Nf}-\mathrm{Au}_{\mathrm{Nps}}$ film are electroactive. This means that more amount of $\mathrm{PS}^{+}$molecules incorporated into the $\mathrm{Nf}-\mathrm{Au}_{\mathrm{Nps}}$ film occupy the $-\mathrm{SO}_{3}^{-}$ionic cluster and interfacial regions and are electroactive.

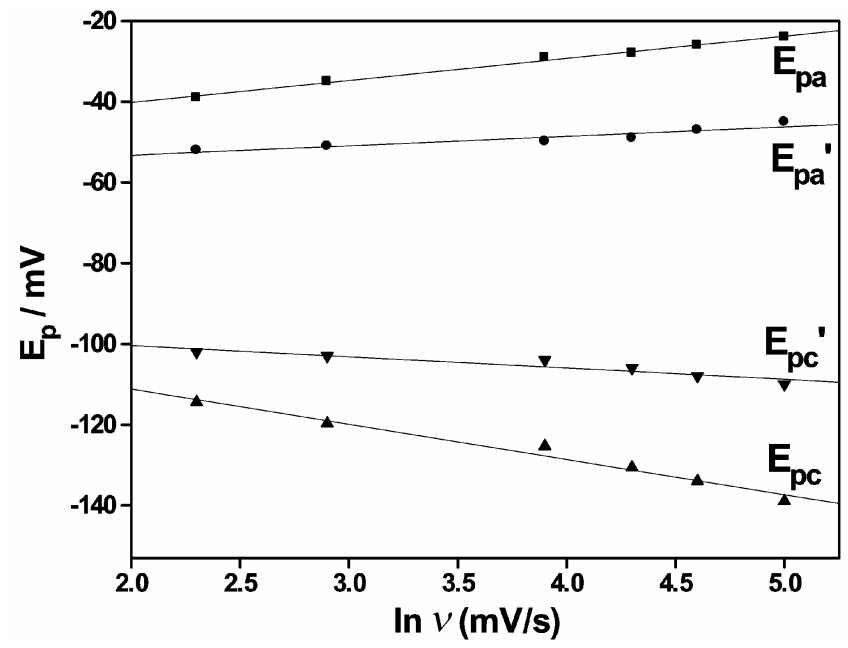

Figure 6. Plot of $\ln v$ against $E_{\mathrm{p}}$ for both anodic $\left(E_{\mathrm{pa}}\right)$ and cathodic $\left(E_{\mathrm{pa}}\right)$ peak potential obtained from the cyclic voltammograms shown in figures 3 and 4 . The value of $\alpha$ was estimated to be 0.38 and 0.46 , respectively from the slope of the plots obtained for $\mathrm{GC} / \mathrm{Nf} / \mathrm{PS}^{+}\left(E_{\mathrm{pa}}\right.$ and $\left.E_{\mathrm{pc}}\right)$ and $\mathrm{GC} / \mathrm{Nf}-\mathrm{Au}_{\mathrm{Nps}} / \mathrm{PS}^{+}$ $\left(E_{\mathrm{pa}^{\prime}}\right.$ and $\left.E_{\mathrm{pc}}\right)$ electrodes. 
3.4 Measurement of electron-transfer rates at modified electrodes

Cyclic voltammetry is a classical technique used for the determination of electron-transfer rate based on the separation of peak potentials $\left(\Delta E_{\text {peak }}\right)$ (Nicholson 1965; Moses and Murray 1976; Laviron 1979; Bard and Faulkner 2000). The electrochemical behaviour of redox molecules at modified electrode deviates from Nernstian behaviour at higher scan rates i.e. becomes quasi-reversible, and the $\Delta E_{\text {peak }}$ increases. The voltammograms shown in figure 3 for $\mathrm{GC} / \mathrm{Nf} / \mathrm{PS}^{+}$electrode show that the peak potential separation $\left(\Delta E_{\text {peak }}\right)$ values increased up to $45 \mathrm{mV}$ when the scan rate increased from 10 to $150 \mathrm{mV} / \mathrm{s}$. However, at the $\mathrm{GC} / \mathrm{Nf}-\mathrm{Au}_{\mathrm{Nps}} / \mathrm{PS}^{+}$electrode (figure 4), relatively a small increase of $18 \mathrm{mV}$ was observed for the same scan rate change. In an attempt to determine the electron transfer coefficient ' $\alpha$ ' and the rate constant ' $k$ ', Laviron's approach was used, which is valid for an electroactive species immobilized on the electrode surface (Laviron 1979). The peak potential $\left(E_{\mathrm{p}}\right)$ values observed for $\mathrm{PS}^{+} / \mathrm{PSH}_{2}^{+}$and $\mathrm{PSH}_{2}^{+} / \mathrm{PS}^{+}$couples at $10,20,50,75,100$ and $150 \mathrm{mV} / \mathrm{s}$ scan rates in the cyclic voltammograms are shown against $\ln v$ (figure 6) to understand the electron transfer process at the $\mathrm{GC} / \mathrm{Nf} / \mathrm{PS}^{+}$and $\mathrm{GC} / \mathrm{Nf}-\mathrm{Au}_{\mathrm{Nps}} / \mathrm{PS}^{+}$ electrodes.

The ' $\alpha$ ' and ' $k$ ' values can be determined from the following relationships

$$
\begin{aligned}
& \alpha=s_{\mathrm{a}} /\left(s_{\mathrm{a}}-s_{\mathrm{c}}\right), \\
& k=\alpha n F v_{\mathrm{c}} / R T \quad \text { or } \quad(1-\alpha) n F v_{\mathrm{a}} / R T,
\end{aligned}
$$

where $v_{\mathrm{c}}$ and $v_{\mathrm{a}}$ are the cathodic and anodic scan rates, respectively and $s_{\mathrm{a}}$ and $s_{\mathrm{c}}$ are the slopes of the anodic and

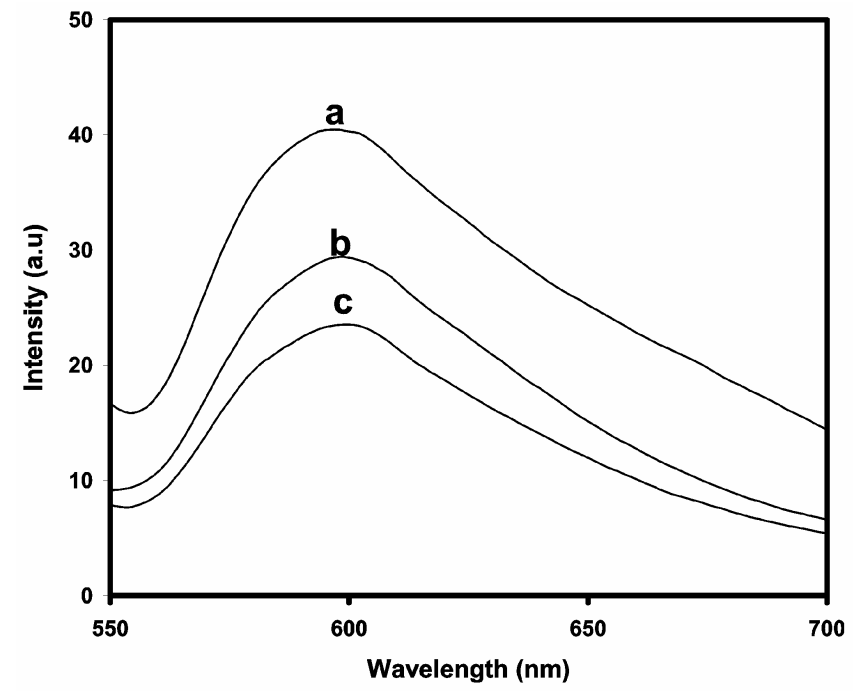

Figure 7. Emission spectra of $\mathrm{PS}^{+}$in $\mathrm{Nf}$ (a) and $\mathrm{Nf}-\mathrm{Au}_{\mathrm{Nps}}$ $(b-c)$ films coated glass plates. The amount of $\mathrm{Au}_{\mathrm{Nps}}$ in the $\mathrm{Nf}$ films are $1.28 \times 10^{-13} \mathrm{~mol}(\mathrm{~b})$ and $2.57 \times 10^{-13} \mathrm{~mol}(\mathrm{c})$. $\lambda_{\mathrm{ex}}=$ $520 \mathrm{~nm}$. cathodic peak currents. Figure 6 shows linear variation of $\ln v$ against $E_{\mathrm{p}}$ for both the anodic and cathodic peak currents. The estimated values of $\alpha$ are 0.38 and 0.46 , which shows that the energy barrier for double layer charging is not symmetric, and the average rate constant, $k$ values are calculated as 1.99 and $2.82 \mathrm{~s}^{-1}$ for $\mathrm{GC} / \mathrm{Nf} / \mathrm{PS}^{+}$and GC/Nf$\mathrm{Au}_{\mathrm{Nps}} / \mathrm{PS}^{+}$electrodes, respectively. A higher rate constant value was observed for $\mathrm{GC} / \mathrm{Nf}-\mathrm{Au}_{\mathrm{Nps}} / \mathrm{PS}^{+}$electrode when compared to the GC/Nf/PS ${ }^{+}$electrode. The ' $k$ ' values are comparable to the reported values at other modified electrodes (Zhao et al 2005). The presence of immobilized $\mathrm{Au}_{\mathrm{Nps}}$ at the GC/Nf electrode not only improved the reversibility of voltammograms but also improved the rate of reaction.

\subsection{Emission spectra of $\mathrm{PS}^{+}$incorporated into $N f-A u_{N p s}$ matrix}

The $\mathrm{PS}^{+}$is an emittive dye and we used emission spectroscopy to probe the interaction between dye and $\mathrm{Au}_{\mathrm{Nps}}$ in the Nf matrix. The emission spectra of $\mathrm{PS}^{+}$incorporated into $\mathrm{Nf}$ and $\mathrm{Nf}-\mathrm{Au}_{\mathrm{Nps}}$ films are shown in figure 7. $\mathrm{PS}^{+}$in Nf film exhibits an intense emission band at $598 \mathrm{~nm}$ when excited at $520 \mathrm{~nm}$ (figure 7a). The incorporated $\mathrm{PS}^{+}$ molecules into the $\mathrm{Au}_{\mathrm{Nps}}$ dispersed $\mathrm{Nf}$ films show the emission band at $598 \mathrm{~nm}$ with lower emission intensity (figure 7(b-c)) when compared to plain Nf film (figure 7a). The amount of $\mathrm{Au}_{\mathrm{Nps}}$ dispersed in $1.6 \mu \mathrm{m}$ thick Nf films are calculated as $1.28 \times 10^{-13} \mathrm{~mol}$ (figure $7 \mathrm{~b}$ ) and $2.57 \times$ $10^{-13} \mathrm{~mol}$ (figure $7 \mathrm{c}$ ). The dye incorporation was carried out in the $\mathrm{Nf}$ and $\mathrm{Nf}-\mathrm{Au}_{\mathrm{Nps}}$ film coated glass plates under similar experimental conditions. Using chronocoulometry experiments the amounts of $\mathrm{PS}^{+}$dye in the $\mathrm{Nf}-\mathrm{Au}_{\mathrm{Nps}}$

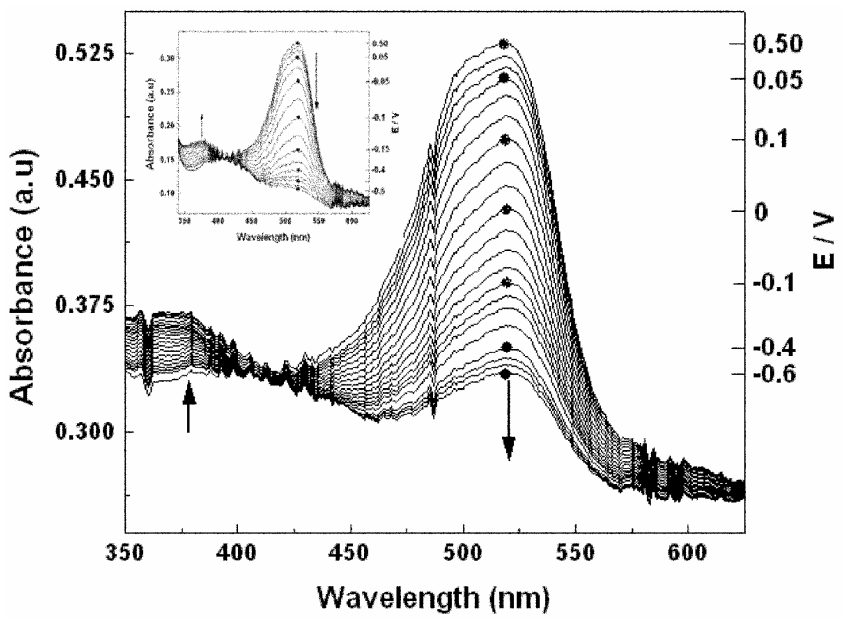

Figure 8. In situ absorption spectral changes observed for ITO/Nf- $\mathrm{Au}_{\mathrm{Nps}} / \mathrm{PS}^{+}$in $0 \cdot 1 \mathrm{M} \mathrm{H}_{2} \mathrm{SO}_{4}$ during the reductive scan from 0.5 to $-0.6 \mathrm{~V}$. Scan rate $=5 \mathrm{mV} / \mathrm{s}$. Absorption spectra were recorded at an interval of $2 \mathrm{~s}$. Other conditions are as in figure 4. Inset: In situ absorption spectral changes observed at ITO/Nf/PS ${ }^{+}$electrode in $0 \cdot 1 \mathrm{M} \mathrm{H}_{2} \mathrm{SO}_{4}$ 
modified electrodes with same film thickness were calculated as $1.34 \times 10^{-8} \mathrm{~mol} / \mathrm{cm}^{2}$ and $1.53 \times 10^{-8} \mathrm{~mol} / \mathrm{cm}^{2}$, respectively. From the emission spectra, a decrease in the emission intensity was observed for $\mathrm{PS}^{+}$in the $\mathrm{Nf}-\mathrm{Au}_{\mathrm{Nps}}$ films. The decrease in the emission intensities indicates that a fraction of excited state $\mathrm{PS}^{+}$molecules were deactivated by the $\mathrm{Au}_{\mathrm{Nps}}$. The immobilization of both $\mathrm{Au}_{\mathrm{Nps}}$ and $\mathrm{PS}^{+}$in the Nf film would enhance the interaction between the $\mathrm{PS}^{+}$dye and $\mathrm{Au}_{\mathrm{Nps}}$ (Ipe et al 2002; Ding et al 2006). The interaction between the cationic dye $\left(\mathrm{PS}^{+}\right)$and the electron rich $\mathrm{Au}_{\mathrm{Nps}}$ is further enhanced by the microheterogeneous environment provided by the Nf film. The improved electrochemical characteristics and the excited state quenching of $\mathrm{PS}^{+}$in the presence of $\mathrm{Au}_{\mathrm{Nps}}$ at the Nf film clearly indicate that this system will find applications in photo-based nanodevices and sensor devices.

\subsection{In situ spectroelectrochemical properties of $P S^{+}$ dye incorporated into $N f$ and $N f-A u_{N p s}$ film modified electrodes}

The in situ absorption spectral changes of $\mathrm{PS}^{+}$at the $\mathrm{ITO} / \mathrm{Nf}-\mathrm{Au}_{\mathrm{Nps}} / \mathrm{PS}^{+}$electrodes were recorded during potential scan. The in situ spectroelectrochemical study provides a tool to understand the redox reaction at the $\mathrm{Nf}-\mathrm{Au}_{\mathrm{Nps}}$ modified electrode and the electrochromic behaviour of the incorporated molecules in the presence of $\mathrm{Au}_{\mathrm{Nps}}$. The in situ spectral changes observed at the ITO/Nf-Au $\mathrm{Au}_{\mathrm{Np}} / \mathrm{PS}^{+}$ and ITO/Nf/PS ${ }^{+}$electrodes in the reductive scan from 0.5 to $-0.6 \mathrm{~V}$ at a scan rate of $5 \mathrm{mV} / \mathrm{s}$ are shown in figure 8 and figure 8 (inset), respectively. Similarly, in situ spectral changes observed in the oxidative scan from -0.6 to

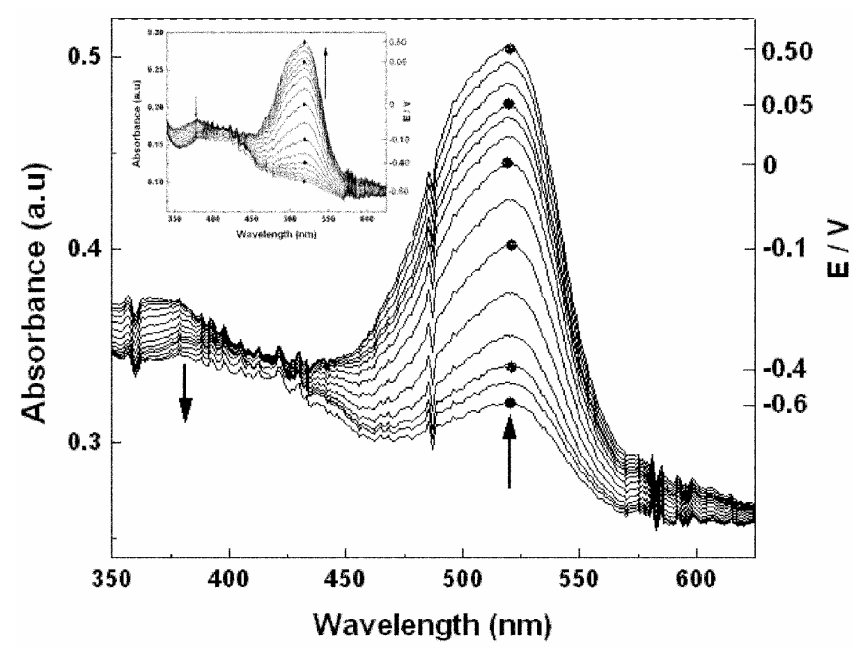

Figure 9. In situ absorption spectral changes observed for ITO/Nf- $\mathrm{Au}_{\mathrm{Nps}} / \mathrm{PS}^{+}$in $0 \cdot 1 \mathrm{M} \mathrm{H}_{2} \mathrm{SO}_{4}$ during the oxidative scan from -0.6 to $0.5 \mathrm{~V}$. Scan rate $=5 \mathrm{mV} / \mathrm{s}$. Absorption spectra were recorded at an interval of $2 \mathrm{~s}$. Other conditions are as in figure 4. Inset: In situ absorption spectral changes observed at ITO/Nf/PS ${ }^{+}$electrode in $0 \cdot 1 \mathrm{M} \mathrm{H}_{2} \mathrm{SO}_{4}$.
$0.5 \mathrm{~V}$ at a scan rate of $5 \mathrm{mV} / \mathrm{s}$ are shown in figure 9 and figure 9 (inset), respectively. The in situ absorption spectra recorded for $\mathrm{PS}^{+}$incorporated into $\mathrm{Nf}-\mathrm{Au}_{\mathrm{Nps}}$ and $\mathrm{Nf}$ films during the reductive scan from 0.5 to $-0.6 \mathrm{~V}$ at a scan rate of $5 \mathrm{mV} / \mathrm{s}$ showed a decrease in the absorbance at $520 \mathrm{~nm}$ due to the reduction of $\mathrm{PS}^{+}$molecules with a simultaneous appearance of a new absorption band at $370 \mathrm{~nm}$ (figure 8) with an isobestic point at $410 \mathrm{~nm}$. At $-0.6 \mathrm{~V}$, most of the $\mathrm{PS}^{+}$molecules underwent reduction and the appearance of a new absorption band was clear at $370 \mathrm{~nm}$. The absorption band at $370 \mathrm{~nm}$ was identified as the two-electron reduced leuco $\mathrm{PSH}_{2}^{+}$(Martin and Dollard 1983; Abraham John and Ramaraj 1997). The formation of leuco $\mathrm{PSH}_{2}^{+}$by photochemical reduction of $\mathrm{PS}^{+}$dye was reported by Gopidas and Kamat $(1989,1990)$ using laser flash photolysis technique. During the oxidative scan from -0.6 to $0.5 \mathrm{~V}$, an increase in absorbance was noticed at $520 \mathrm{~nm}$ with a simultaneous decrease in absorbance at $370 \mathrm{~nm}$. At the end of the oxidative scan from -0.6 to $0.5 \mathrm{~V}$, the original absorption spectrum was recovered (figure 9).

The absorption spectra of $\mathrm{PS}^{+}$in water and $\mathrm{Nf}$ film exhibited the characteristic absorption band due to monomer $\mathrm{PS}^{+}$at $520 \mathrm{~nm}$. When Au nanoparticle $\left(2.57 \times 10^{-13} \mathrm{~mol}\right)$ was dispersed in $0.5 \% \mathrm{Nf}$ solution and coated on the electrode surface an increase in the absorbance due to $\mathrm{PS}^{+}$in the $\mathrm{Nf}-\mathrm{Au}_{\mathrm{Nps}}$ film was observed when compared to the ITO/Nf/PS ${ }^{+}$electrode. The absorption band due to $\mathrm{PS}^{+}$ was not shifted at the ITO/Nf $\mathrm{Nps}_{\mathrm{Nps}}-\mathrm{Au}$ electrode. The $\mathrm{Au}_{\mathrm{Nps}}-$ dye $\left(\mathrm{Au}-\mathrm{PS}^{+}\right)$assemblies combine to form larger clusters within the film because of surface charge neutralization (Awan and Shah 1997) and modulate the arrangement of $\mathrm{PS}^{+}$molecules in the Nf film.

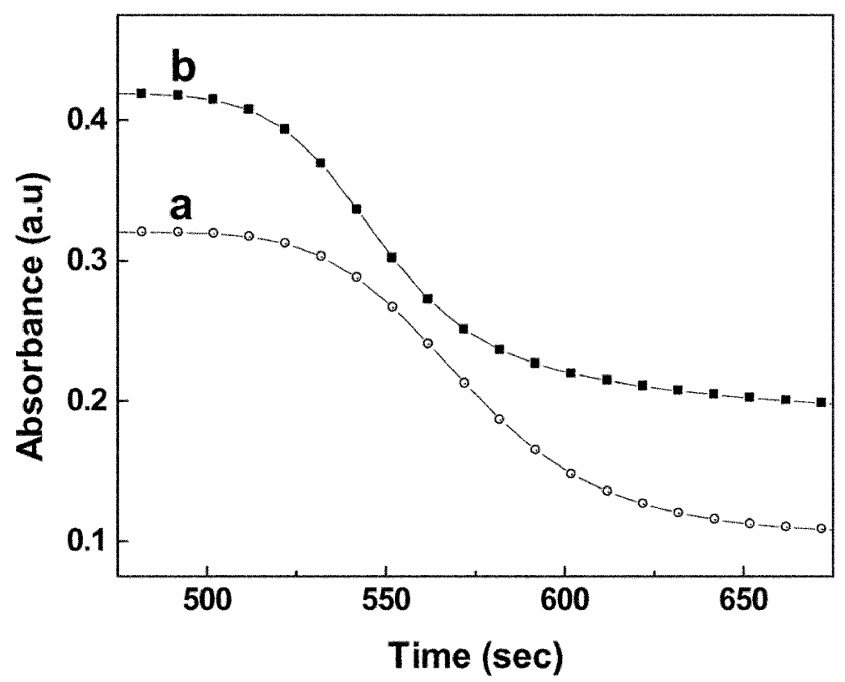

Figure 10. Absorbance changes observed at $520 \mathrm{~nm}$ due to $\mathrm{PS}^{+}$reduction with time during the reductive scan from 0.5 to $-0.6 \mathrm{~V}$. Spectral changes recorded for ITO/Nf/PS ${ }^{+}$(a) and ITO/Nf-Au $\mathrm{Nps}_{\mathrm{NpS}} / \mathrm{PS}^{+}$(b) electrodes in $0.1 \mathrm{M} \mathrm{H}_{2} \mathrm{SO}_{4}$. Absorption spectral changes were recorded at $2 \mathrm{~s}$ interval. 
Figure 10 shows the plot of change in absorbance of $\mathrm{PS}^{+}$at $520 \mathrm{~nm}$ with respect to time during the reductive scan at ITO/Nf/Au $\mathrm{Nps}_{\mathrm{N}}$ (figure 10a) and ITO/Nf (figure 10b) electrodes. During the reductive scan between 0.5 and $-0.6 \mathrm{~V}$, the absorbance due to $\mathrm{PS}^{+}$decreased rapidly at the ITO/Nf-Au $\mathrm{Au}_{\mathrm{Nps}}$ electrode in about $80 \mathrm{~s}$ whereas at the ITO/Nf electrode the absorbance due to $\mathrm{PS}^{+}$decreased slowly in about $150 \mathrm{~s}$. The redox process of $\mathrm{PS}^{+}$dye with the formation of short lived leuco $\mathrm{PSH}_{2}^{+}$dye is clearly shown in the in situ spectral changes. The in situ spectral study clearly shows that the dispersion of $\mathrm{Au}_{\mathrm{Nps}}$ in the $\mathrm{Nf}$ film mediates the electron transfer of $\mathrm{PS}^{+}$molecule and improves the redox switching process. The rapid spectral change during the redox process observed at the $\mathrm{Nf}-$ $\mathrm{Au}_{\mathrm{Nps}} / \mathrm{PS}^{+}$film shows that the $\mathrm{Nf}-\mathrm{Au}_{\mathrm{Nps}}$ modified electrode could be used for electrochromic display devices, electrocatalysis and sensor applications. The advantageous properties of this modified electrode are the permselective and microheterogeneous nature of $\mathrm{Nf}$ film, the large surface area and the fast electron mediation effect of $\mathrm{Au}_{\mathrm{Nps}}$.

\section{Conclusions}

The electrochemical and in situ spectral characteristics of $\mathrm{PS}^{+}$dye incorporated into the $\mathrm{Nf}-\mathrm{Au}_{\mathrm{Nps}}$ film modified electrode were studied by means of electrochemical and in situ spectroelectrochemical techniques. The $\mathrm{PS}^{+}$molecules interact strongly with $\mathrm{Au}_{\mathrm{Nps}}$ as confirmed by cyclic voltammetric and spectroelectrochemical studies. The incorporation of $\mathrm{PS}^{+}$dye into $\mathrm{Au}_{\mathrm{Nps}}$ immobilized $\mathrm{Nf}$ modified electrode enhances the absorption sensitivity of $\mathrm{PS}^{+}$and modulates the molecular arrangement of $\mathrm{PS}^{+}$ molecules. The $\mathrm{Au}_{\mathrm{Nps}}$ immobilized in Nf matrix improved the reversibility of $\mathrm{PS}^{+}$molecules and the rate of the reaction. The incorporated $\mathrm{PS}^{+}$into the $\mathrm{Nf}-\mathrm{Au}_{\mathrm{Nps}}$ film is fluorescent, and this property suggests possible applications in fabricating biomolecular labels and design of novel photo-based nanodevices for sensing and switching. The rapid in situ spectral changes of the $\mathrm{PS}^{+}$redox process shows that the $\mathrm{Au}_{\mathrm{Nps}}$ immobilized Nf matrix could be useful in electrocatalytic and electrochromic applications.

\section{Acknowledgements}

The financial support from the Department of Science and Technology (DST) is gratefully acknowledged. One of the authors (TS) is recipient of a CSIR-SRF fellowship.

\section{References}

Abraham John S and Ramaraj R 1996 Langmuir 125689 Abraham John S and Ramaraj R 1997 J. Electroanal. Chem. $\mathbf{4 2 4} 49$
Aray Y, Marquez M, Rodriguez J, Coll S, Simón-Manso Y, Gonzalez C and Weitz D A 2003 J. Phys. Chem. B107 8946

Awan M A and Shah S S 1997 Colloids Surf. A122 97

Barazzouk S, Kamat P V and Hotchandani S 2005 J. Phys. Chem. B109 716

Bard A J and Faulkner L R 2000 Electrochemical methods (New York: Wiley)

Campbell C T 2004 Science 306234

Chiba K, Ohsaka T and Oyama N 1987 J. Electroanal. Chem. 217239

Clapp A R, Medintz I L, Fisher B R, Anderson G P and Mattoussi H 2005 J. Am. Chem. Soc. 1271242

Dai X, Wildgoose G G, Salter C, Crossley A and Compton R G 2006 Anal. Chem. 786102

Daniel M -C and Astruc D 2004 Chem. Rev. 104293

Daweipan W T 2004 J. Electroanal. Chem. 572109

Ding Y, Zhang X, Liu X and Guo R 2006 Langmuir 222292

Easwaramoorthy S and Natarajan P 2005 Microporous and Mesoporous Materials 86185

Eckenrode H M, Jen S -H, Han J, Yeh A -G and Dai H -L 2005 J. Phys. Chem. B109 4646

Eggins B R 2002 Chemical sensors and biosensors (New York: Wiley)

Ganesan V, Abraham John S and Ramaraj R 2001 J. Electroanal. Chem. 502167

George A, Graf W, Neumann R and Wittwer V 2000 Solid State Ionics 127319

Gonzalez-Garcia C M, Gonzalez-Martin M L, Gallardo-Moreno A M, Gomez-Serrano V, Labajos-Broncano L and Bruque J M 2002 J. Colloid Interface Sci. 24813

Gopidas K R and Kamat P V 1989 Langmuir 522

Gopidas K R and Kamat P V 1990 J. Phys. Chem. 944723

Guadalupe A R, Liu KE and Abruna H D 1991 Electrochim. Acta 36881

Haruta M 2004 in Encyclopedia of nanoscience and nanotechnology (ed.) H S Nalwa (Stevenson Ranch, CA: American Scientific Publishers) Vol. 1

Henglein A 1989 Chem. Rev. 891861

Hoogvliet J C, Dijksma M, Kamp B and van Bennekom W P 2000 Anal. Chem. 722016

Hu J, Zhang J, Liu F, Kittredge K, Whitesell J K and Fox M A 2001 J. Am. Chem. Soc. 1231464

Ipe B I, Thomas K G, Barazzouk S, Hotchandani S and Kamat P V 2002 J. Phys. Chem. B106 18

Kreibig U and Vollmer M 1995 Optical properties of metal clusters (Berlin: Springer)

Laviron E J 1979 Electroanal. Chem. 10119

Linsebigler A L, Lu Jr G Q and Yates J T 1995 Chem. Rev. 95 735

Martin C R and Dollard K A 1983 J. Electroanal. Chem. 159 127

Martin C R, Rubinstein I and Bard A J 1984 J. Am. Chem. Soc. 1044817

Mauritz K A and Moore R B 2004 Chem. Rev. 1044535

Moses P R and Murray R W 1976 J. Am. Chem. Soc. 987435

Neumann-Spallart M and Kalyanasundaram K 1982 J. Phys. Chem. 862681

Nicholson R S 1965 Anal. Chem. 371351

Niemeyer C M 2001 Angew. Chem. Int. Ed. 404128

Olah G A, Iyer P S and Prakash G K S 1986 Synthesis 513 and references therein 
Radovic L R 1999 in Surfaces of nanoparticles and porous materials (eds) J A Schwarz and C I Contescu (New York: Marcel Dekker) Vol. 78

Ramaraj R and Natarajan P 1989 J. Chem. Soc., Faraday Trans. $\mathbf{8 5} 813$

Rodriguez J A, Liu G, Jirsak T, Hrbek J, Chang Z, Dvorak J and Maiti A 2002 J. Am. Chem. Soc. 1245242

Selvaraju T and Ramaraj R 2005 J. Electroanal. Chem. 585290

Shenhar R and Rotello V M 2003 Acc. Chem. Res. 36549

Shipway A N, Lahav M and Willner I 2000 Adv. Mater. 12993

Subramanian V, Wolf E E and Kamat P V 2004 J. Am. Chem. Soc. 1264943

Sudeep P K, Ipe B I, George Thomas K, George M V, Barazzouk S, Hotchandani S and Kamat P V 2002 Nano Lett. 229

Su K -H, Wei Q -H, Zhang X, Mock J J, Smith D R and Schulz S 2003 Nano Lett. 31087
Tanaka K, Tokuda K and Ohsaka T 1993 J. Chem. Soc., Chem. Commun. 231770

Thomas K G and Kamat P V 2003 Acc. Chem. Res. 36888

Trasatti S and Petrii OA 1991 Pure and Appl. Chem. 63 711

Wildgoose G G, Banks C E and Compton R G 2006 Small 2 182

Xiao Y, Patolsky F, Katz E, Hainfeld J F and Willner I 2003 Science 2991877

Xu Q, Gates B D and Whitesides G M 2004 J. Am. Chem. Soc. 1261332

Yan B, Yang Y and Wang Y 2003 J. Phys. Chem. B107 9159

Yao J N, Yang Y A and Loo B H 1998 J. Phys. Chem. B102 1856

Zhao G-C, Yin Z -Z, Zhang L and Wei X-W 2005 Electrochem. Commun. 7256 and references therein 